\title{
Primary Hyperparathyroidism Presented With Peripheral Brown Tumor In The Oral Cavity: A Case Report
}

\author{
Gulsah Elbuken, Bora Ozan, Onur Ozturk, Bahadir Yazicioglu, \\ Recep Aktimur, Zulay Kazak, Ilsen Semiha Kececi, Sema Kolcu- Bulbul, Mehmet Derya Demirag
}

Introduction: Parathyroid hormone (PTH) is the chief regulator of calcium homeostasis in the human body. Primary hyperparathyroidism (PHPT) occurs in a setting of excessive PTH secretion with an autonomous parathyroid gland which resulting in hypercalcemia [1]. Most patients with PHPT have a single adenoma (about $80 \%$ of cases), but multigland disease can occur in $10 \%-15 \%$ of cases and double adenomas in $4 \%-5 \%$ [2]. Parathyroid carcinoma is a rare cause (usually less than $1 \%$ of patients) of hyperparathyroidism $[3,4]$. There is a great variation in the manifestations of PHPT. The clinical presentation of PHPT is changing from a severe disease with nephrolithiasis and metabolic bone disease to mild asymptomatic disease [5,6]. The most common clinical presentation of PHPT is asymptomatic hypercalcemia with an elevated or high-or normal intact PTH level. Patients with hypercalcemia may present with vague constitutional symptoms, anorexia, lethargy, or polydipsia and polyuria [7-9]. Less specific features of PHPT are fatigue, proximal muscle weakness, mild cognitive disturbances, hypertension, left ventricular hypertrophy, valvular calcification, and cardiovascular mortality $[2,10]$. Classic skeletal lesions, which are bone resorption, bone cysts, brown tumors and generalized osteopenia, occur in less than $5 \%$ of cases [11]. PHPT affects compact bone more than trabecular bone with particular sensitivity in the cortices of long bones leading to subperiostal bone resorption (seen as periosteal elevation on plain radiography) [12]. PHPT is prone to cause loss of the lamina dura [13].

Giant cell lesions of bone share similar clinical, radiological, and histological features. The most challenging differential diagnosis is between giant cell tumor and brown tumor due to hyperparathyroidism. Giant cell lesion associated with hyperparathyroidism is known as "brown tumor". It is a giant cell granuloma which occurs in osteitis fibrosis cystica. It represents the terminal stage of the bone remodelling processes occurring as a result of peritrabecular fibrosis and osteoclastic activity $[14,15]$. The incidence of brown tumor associated with hyperparathyroidism is rare $(0.1 \%)$. Brown tumors can occur as solitary or multiple lesions in any bone. The term of "brown tumor" comes from the colour of lesion; which results from the vascularity, hemorrhage and deposits of hemosiderin [16]. These tumors are usually soft, painless, minimally tender, and appear elastic on palpation. Symptoms result from the considerable dimensions of the tumor and its localization, but in most cases maxillary tumor is not painful. Radiographically, they appear as well demarcated monolocular or multilocular osteolytic lesions. The mandible is the predominantly affected site in the maxillofacial area. Maxillary involvement is rare [17-22].

Case Report: A 50-year old man was admitted to Oral Medicine Department in Samsun Oral Medicine Hospital for evaluation of an oral cavitiy lesion. Physical extraoral examination was not remarkable and facial deformity was not observed. In his medical history there was not a renal failure or any disease including bone metabolism. In physical intraoral examination there was a sessile swelling on the anterior region of the maxilla, in $27 \times 16 \times 13 \mathrm{~mm}$ diameter. The lesion was surgically removed and histopathological analysis revealed a tumor, including ovoid to spindle-shaped mesencymal cells with focal aggregates of multinucleated giant cells throughout the lesion (Figure 1).

The patient was referred to our outpatient clinic of Endocrinology and Metabolism of Samsun Training and Research Hospital. Blood analysis demonstrated PTH level of 355 pg/mL (normal range:15-65). 
Serum calcium and alkaline phosphatase levels were also upper [10.6mg/dL (8.7-10.4); $430 \mathrm{U} / \mathrm{L}$ (45129), respectively] than normal limits whereas phosphorus level was lesser. Biochemical tests were summarized at Table 1. Neck ultrasonography revealed a solitary lesion on the right parathyroid region (Figure 2). Dual phase 99mTc-sestamibi parathyroid scintigraphy imaging (Tc99 m MIBI) detected a mass nearby inferior right thyroid gland, compatible with a parathyroid adenoma (Figure 3). A diagnosis of brown tumor associated with PHPT was made.

After removing of the primary lesion of oral cavity, the present case was also treated by surgical removing of parathyroid adenoma which resulting with PHPT.

Discussion: PHPT is one of the most common endocrinological disorders [1]. Single gland parathyroid adenoma is the most common cause of PHPT. Although PHPT is generally an asymptomatic disease detected by an incidental finding of hypercalcemia; in several cases, it was diagnosed by overt bone disease. Bone involvement is the late manifestation of PHPT [19]. The ribs, clavicles, pelvic girdle, hand and the mandible are the most involved bones [20,21]. The jaw bones are commonly affected by brown tumors in PHPT, and radiologically a generalized loss of lamina dura surroinding the roots of the teeth, loss of cortication in maxillary sinus and around the inferior alveolar canal, and of the trabecular pattern of the jaws [14]. Peripheral manifestation of brown tumor on the oral cavity is rare as our case report, the clinical appearance simulates peripheral giant cell granuloma. The brown tumor is a kind of giant cell lesion and appears as multiple expansive osteolytic lesions of the bone. It is so difficult to distinguish histopathologically brown tumor from other giant cell lesions. So, the clinical diagnosis is made based the associacion with PHPT [22].

The most useful therapy for patients with brown tumors is surgical excision of bone lesions and therapy (surgical or medical) for primary or secondary HPT. If PHPT due to a parathyroid adenoma (or adenomas), parathyroidectomy is the definitive cure. Surgery has a very high long-term success rate and minimal morbidity [7,8]. Medical therapy, such as calcimimetics, may gain popularity for patients with hypercalcemia who can not undergo surgery. Although studies show that cinacalcet, versus placebo, effectively lowers both calcium and PTH levels, there is no significant increase in bone mineral density [23-25]. Multiple studies have shown that bisphosphonates improve bone mineral density on DXA scan in patients with PHPT $[26,28]$. If preservation of bone mineral density is the primary goal of treating asymptomatic PHPT, the agent of choice should be a bisphosphonate [7].

Conclusion: We present a rare case of maxillar brown tumor associated with PHPT simulating a peripheral giant cell lesion. And we also emphasize the consultation between the oral and maxillofacial surgeons, dentists, endocrinologists and radiologists. 
Table 1: Biochemical tests of the patient showing abnormalities.

\begin{tabular}{|l|l|l|}
\hline Parameter & Patient & Normal Range \\
\hline Cakcium & $10.6 \mathrm{mg} / \mathrm{dL}$ & $8.7-10.4 \mathrm{mg} / \mathrm{dL}$ \\
\hline Phosphorus & $1.9 \mathrm{mg} / \mathrm{dL}$ & $2.4-5.1 \mathrm{mg} / \mathrm{dL}$ \\
\hline Albumin & $4.2 \mathrm{~g} / \mathrm{dL}$ & $3.2-4.8 \mathrm{~g} / \mathrm{dL}$ \\
\hline Alkaline phosphatase & $430 \mathrm{U} / \mathrm{L}$ & $45-129 \mathrm{U} / \mathrm{L}$ \\
\hline Parathormone & $355 \mathrm{pg} / \mathrm{mL}$ & $15-65 \mathrm{pg} / \mathrm{mL}$ \\
\hline 25-OH-vitamin D & $25 \mathrm{ng} / \mathrm{mL}$ & $25-80 \mathrm{ng} / \mathrm{mL}$ \\
\hline
\end{tabular}
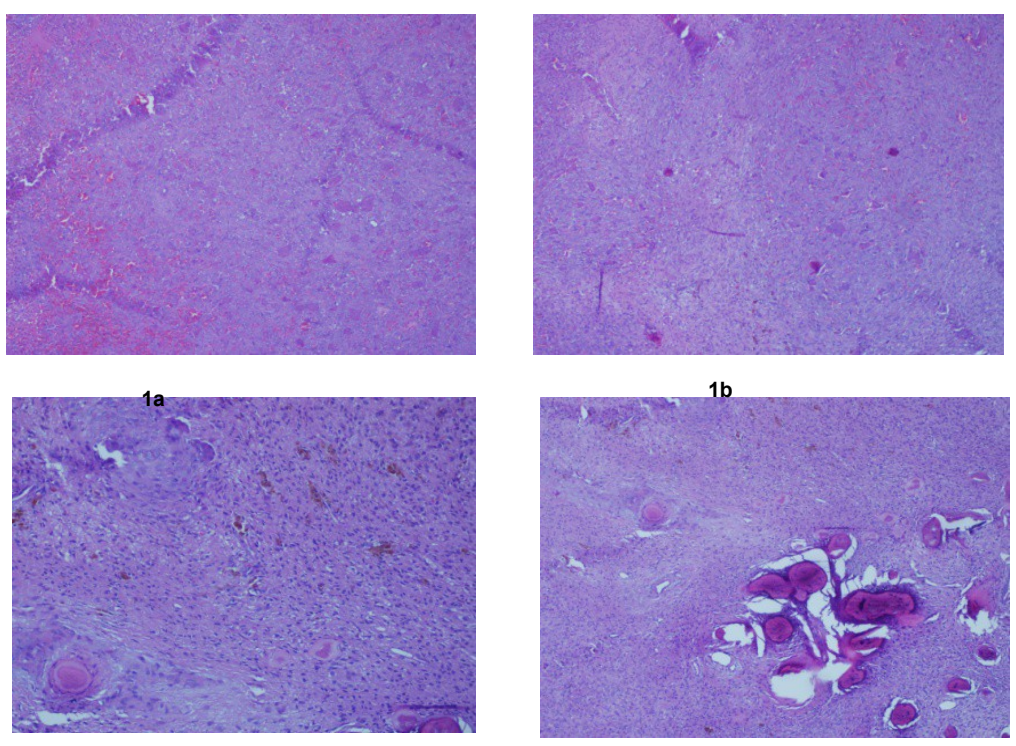

1c

1d

Figure1:Histopathologicalappearanceofthelesion.

Mononuclearovoidandmultinucleatedgiantcells

(H\&E, 1a:10x10, 1b: 10x10, 1c:10x40, 1d:10x20). 


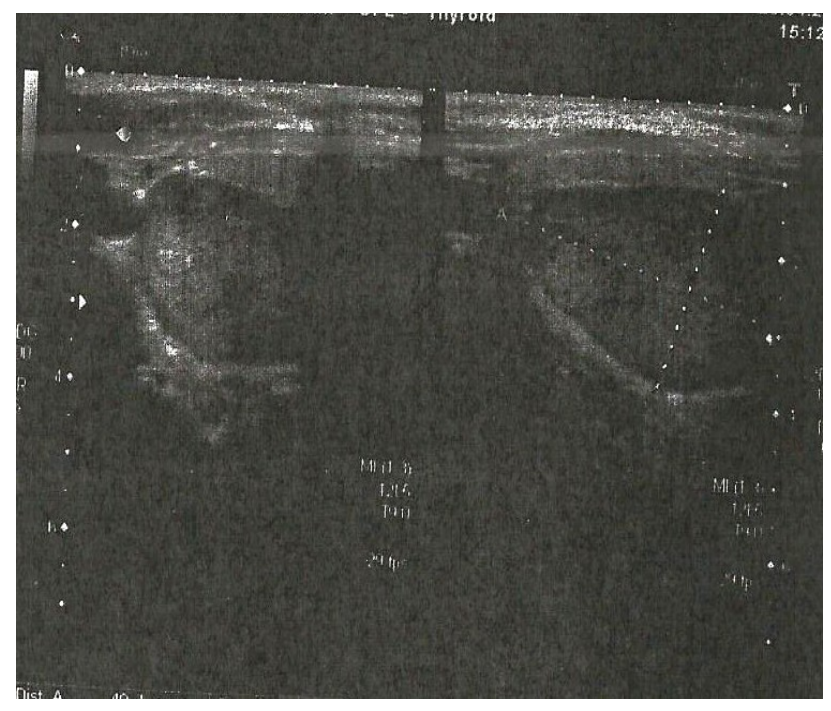

Figure2:Neckultrasoundshows well-defined homogenoushypoechoeicsolid mass lesion in relation to the posterior aspect of the inferior pole of therightlobe of thyroid.

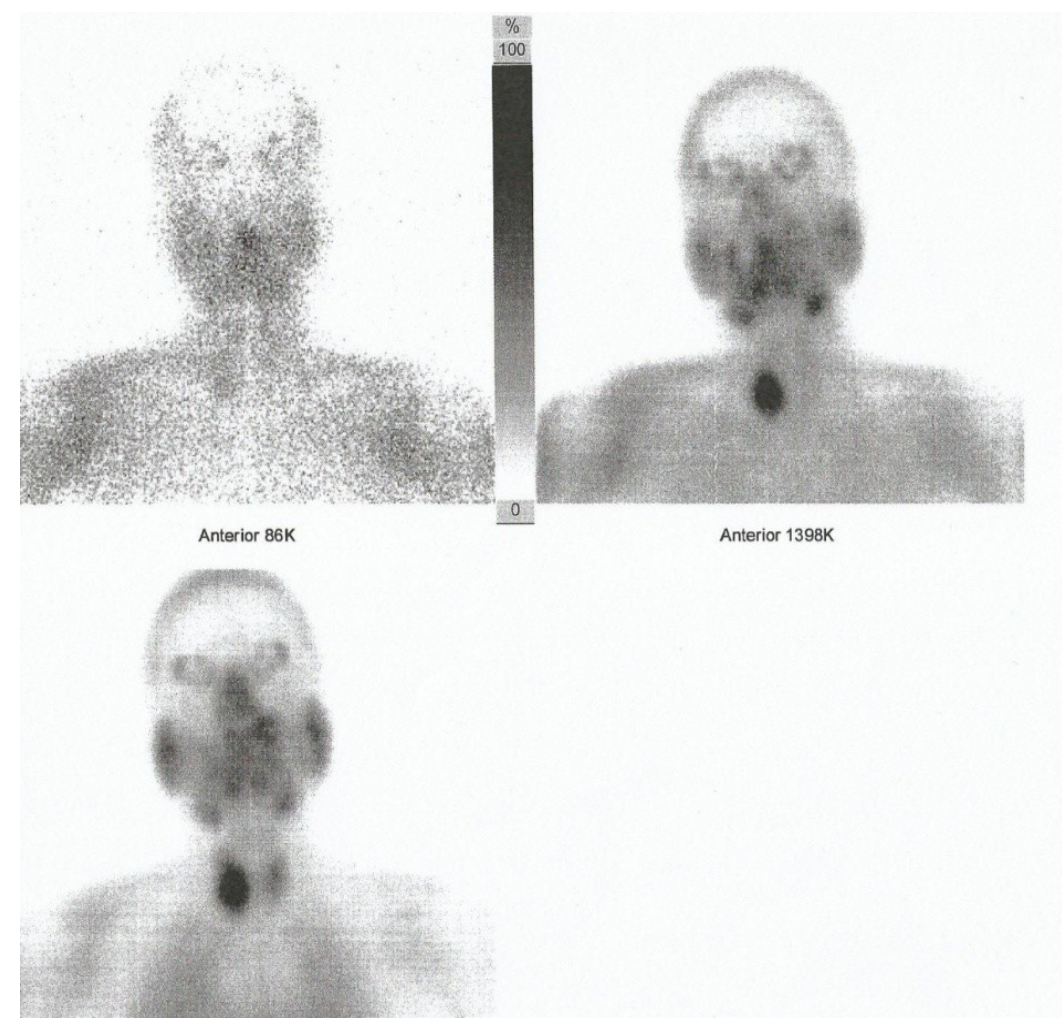

Figure3:Tc99m-sestamibi parathyroidscintigraphy,revealed an area with increased uptake in the lowerrightthyroid lobe and another area with marked uptakelowerthan this level. 


\section{References:}

1. MacKenzie-Feder J, Sirrs S, Anderson D, Sharif J, Khan A. Primary Hyperparathyroidism: An Overview. International J Endocr 2011; Article ID 251410, pg:1-8.

2. Felder EA, Kandil E. Primary hyperparathyroidism. Otolaryn Clin of North Am 2010; 43(2):417-32.

3. Marx SJ. Hyperparathyroid and hypoparathyroid disorders. N Engl J Med 2000;1863-75.

4. Shane E. Clinical review 122: parathyroid carcinoma. J Clin Endocr Metab 2001;86(2):485-93.

5. Bilezikian JP. Nephrolithiasis in primary hyperparathyroidism. In: Coe FL, Favus MJ, Pak CYC, Parks JH, Preminger GM, eds. Kidney Stones: medical and surgical treatment. Philadelphia: Lippincott-Raven. pp: 783-802, 1996.

6. Fraser WD. Hyperparathyroidism. The Lancet 2009;374 (9684): 145-158.

7. Khan AA, Bilezikian JP, Potts JTJ. The diagnosis and management of asymptomatic primary hyperparathyroidism revisited. J Clin Endocr Metab 2009;15(5):333-4.

8. Bandeira F, Griz L, Chaves N, Carvalho NC, Borges LM, Lazaretti-Castro M, Borba V, de Castro LC, Borges JL, Bilezikian J. Diagnosis and management of primary hyperparathyroidism--a scientific statement from the Department of Bone Metabolism, the Brazilian Society for Endocrinology and Metabolism. Arq Bras Endocrinol Metabol. 2013 Aug;57(6):406-24.

9. Cope O. The study of hyperparathyroidism at the Massachusetts General Hospital. N Engl J Med 1966;274:1174-82.

10. Silverberg SJ. Non-classical target organs in primary hyperparathyroidism. J Bone Miner Res 2002;17(2):117-25.

11. Wishart J, Horowitz M, Need A, Nordin BE. Relationship between forearm and vertebral mineral density in postmenopausal women with primary hyperparathyroidism. Arch Intern Med 1990;150:1329-31.

12. Khan AJH, Pender A, Wei X, Potter M. I-cell disease (mucolipidosis II) presenting as neonatal fractures: a case for continued monitoring of serum parathyroid hormone levels. Clin Ped Endocrinol 2008;17(3):81-5.

13. Bramley P, Dwyer D. Primary hyperparathyroidism. Its effect on a mother and her children. Oral Surgery Oral Med Oral Pathol 1970;30:464-71.

14. Som PM, Lawson W, Cohen BA. Giant-cell lesions of the facial bones. Radiology 1983;147:129-34.

15. Palot Manzil FF, Bhambhvani P, Vattoth S, Subedi SK, Bag AK, O'Malley JP. Primary hyperparathyroidism-related brown tumors mimicking other giant cell-containing skeletal tumors: role of correlative imaging in diagnosis. J Nucl Med Technol 2013;41(1):46-8.

16. Shang ZJ, Li ZB, Chen XM, Li JR, McCoy JM. Expansile lesion of the mandible in a 45-year-old man. J Oral Maxillofac Surg 2003;61:621-5.

17. Triantafillidou K, Zouloumis L, Karakinaris G, Kalimeras E, Iordanidis F. Brown tumors of the jaws associated with primary or secondary hyperparathyroidism. A clinical study and review of the literature. Am J of Otolaryngol, 2006;27:4281-6.

18. Martinez-Gavidia EM, Bagan JV, Milian- Masanet MA, Lloria de A, Perez-Valles A. Highly aggressive Brown tumour of the maxilla as first manifestation of primary hyperparathyroidism. Int J Oral Maxillofac Surg 2000;29:447-9.

19. Daniels JS. Primary hyperparathyroidism presenting as a palatal Brown tumor. Oral Surgery Oral Med Oral Pathol Oral Radiol Endoc 2004;98:409-13.

20. Guney E, Yigitbasi OG, Bayram F, Ozer V, Canoz O. Brown tumor of the maxilla associated with primary hyperparathyroidism. Auris Nasus Larynx 2001;28:369-72.

21. Keyser JS, Postma GN. Brown tumor of the mandible. Am J Otolaryngol 1996;17:407-10.

22. Dusunsel R, Guney E, Gunduz Z, Poyrazoglu MH, Yigitbasi O, Kontas O. Maxillary Brown tumor caused by secondary hyperparathyroidism in a boy. Pediatr Nephrolog 2000;14:529-30.

23. Rothe HM, Liangos O, Biggar P, Petermann A, Ketteler M. Cinacalcet_treatment of_primary hyperparathyroidism. Int J Endocrinol. 2011;2011:415719.

24. Duntas LH, Stathatos N. Cinacalcet_as alternative treatment for_primary hyperparathyroidism: achievements and prospects. Endocrine. 2011 Jun;39(3):199-204

25. Peacock M, Bolognese MA, Borofsky M, Scumpia S, Sterling LR, Cheng S, Shoback D. Cinacalcet_treatment of primary hyperparathyroidism: biochemical and bone densitometric outcomes in a five-year study. J Clin Endocrinol Metab. 2009 Dec;94(12):4860-7.

26. Khan AA, Bilezikian JP, Kung A, Dubois SJ, Standish TI, Syed ZA. Alendronate_therapy_in men with_primary hyperparathyroidism. Endocr Pract. 2009 Nov-Dec;15(7):705-13.

27. Chow CC, Chan WB, Li JK, Chan NN, Chan MH, Ko GT, Lo KW, Cockram CS. Oral_alendronate_increases bone mineral density in postmenopausal women with_primary hyperparathyroidism. J Clin Endocrinol Metab. 2003 Feb;88(2):581-7.

28. Parker CR, Blackwell PJ, Fairbairn KJ, Hosking DJ. Alendronate_in the treatment of primary_hyperparathyroid-related osteoporosis: a 2-year study. J Clin Endocrinol Metab. 2002 Oct;87(10):4482-9. 
